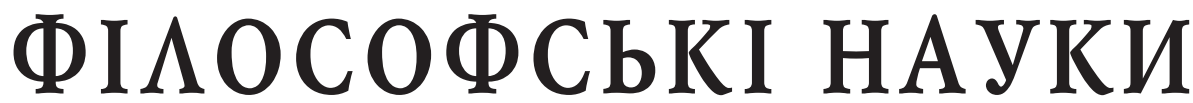

DOI: https://doi.org/10.32839/2304-5809/2021-8-96-7

УДК $316.285(159.964 .26)$

Воропаева Т.С. ${ }^{1}$, Авер'янова Н.М. ${ }^{2}$

Київський національний університет імені Тараса Шевченка

\section{РОЗВИТОК КОНФЛІКТОЛОГІЧнИХ ІДЕЙ В ІСТОРІї ФІЛОСОФСЬКОї ДУМКИ (ВІД ЗИГМУНДА ФРОЙДА ДО НАШИХ ДНІВ)}

Анотація. У статті розглядаються особливості розвитку конфліктологічних ідей в історії фрілософської думки (від Зигмунда Фройда до наших днів). На рубежі XIX-XX ст. конфліктна проблематика опрацьовувалась у рамках соціально-політичних і правових концепцій суспільного розвитку людства. На початку XX ст. починається поступова систематизація конфліктологічних знань. На становлення кондліктології як науки суттево вплинули зарубіжні психологічні дослідження конфліктів першої половини ХХ ст. у рамках кількох напрямків. Спроба формування загальної теорії конфлікту у 1950-1970-тих роках базувалась на вивченні динамічно-структурних і фрункціональних характеристик конфліктів. На рубежі 1960-1970-х років починає формуватися самостійний напрям з вивчення переговорного процесу як частини конфліктної взаємодії. Найвідомішою є концепція Гарвардської школи конфліктології, що базується на інтерпретації конфолікту як конструктивної сили та концепції «принципових переговорів» Р. Фішера і У. Юрі. Нині конфліктологічні дослідження у країнах Заходу здійснюються за такими напрямками: 1) теоретико-ігровий (який започаткував М. Дойч); 2) теорія організаційних систем (яку започаткували Р. Блейк, Дж. Мутон); 3) теорія і практика переговорного процесу (яку започаткували Д. Прюітт, Д. Рубін, Р. Фішер, У. Юрі).

Ключові слова: конфлікт, конфліктологічні ідеї, конфліктологія як наука, фрілософрська думка.

Voropayeva Tetiana, Averianova Nina

Taras Shevchenko National University of Kyiv

\section{DEVELOPMENT OF CONFLICTOLOGICAL IDEAS IN THE HISTORY OF PHILOSOPHICAL THOUGHT (FROM SIGMUND FREUD TO THE PRESENT DAY)}

Summary. The article considers the peculiarities of the development of conflictological ideas in the history of philosophical thought (from Sigmund Freud to the present day). In the history of the development of conflictological thought in the framework of foreign philosophy, psychology and sociology, certain patterns and conceptual diversity can be traced. At the turn of the XIX-XX centuries, conflict issue was studied within the framework of socio-political and legal concepts of social development of mankind. At this time there was a significant interest of researchers in the dialectical concept of Hegel, who understood the conflict as the basis of general development. Within the framework of the socio-humanities of that time, a conflictological direction was gradually formed, which was based primarily on the ideas of Karl Marx, who emphasized that social conflict is the highest form of social contradictions, the energy of which can be a major factor in social progress. In the early twentieth century, the gradual systematization of conflictological knowledge begins. The formation of conflictology as a science was significantly influenced by foreign psychological studies of conflicts in several areas in the first half of XX century. In the second half of XX century, the so-called destructive conceptions of conflict as a social anomaly are gradually losing popularity (T. Parsons, E. Mayo). The main conflictological studies took place within the framework of Lewis Coser's theory of positive-functional conflict, Ralf Dahrendorf's theory of the conflict model of society and Kenneth Boulding's general theory of conflict. The attempt to form a general theory of conflict in the 1950s and 1970s was based on the study of the dynamic-structural and functional characteristics of conflicts. At the turn of the 1960s and 1970s, an independent direction of studying the negotiation process as part of conflict interaction began to take shape. The most famous is the concept of the Harvard School of Conflictology, which is based on the interpretation of conflict as a constructive force and the concept of "principled negotiations" by R. Fischer and W. Yuri. Currently, conflict studies in Western countries are carried out in the following areas: 1) game theory (initiated by M. Deutsch); 2) the theory of organizational systems (initiated by R. Blake, J. Mouton); 3) theory and practice of the negotiation process (initiated by D. Pruitt, D. Rubin, R. Fischer, W. Yuri).

Keywords: conflict, conflictological ideas, conflictological researches, conflictology as a science, philosophical thought.

Постановка проблеми. Актуальність проблеми розвитку конфрліктологічних ідей в історії фрілософрької думки (зокрема, в період від Зигмунда Фройда до наших днів) не викликае сумнівів, оскільки ця проблема є суттевою у корпусі досліджень сучасної соціо- гуманітаристики, присвячених питанню російсько-українського збройного конфрлікту неоколоніального типу, що триває на території України вже восьмий рік. Для України конструктивне вирішення цього питання є невідкладним, адже припинення російсько-українського збройного 
конорікту неоколоніального типу, деконоліктизація українського суспільства та реінтеграція населення окупованих територій є надзвичайно важливими $[4 ; 6]$. Вирішення таких складних питань має базуватись на основі сучасних теоретико-методологічних засад вивчення процесів конфрліктизації та деконфрліктизації соціуму, а також на основі інтегративного підходу.

Аналіз наукових публікацій. Відомо, що історія фрілософської думки містить досить багато конорліктологічних ідей. Основні 3 них представлені у творах багатьох мислителів і вчених, серед них: Лао-Цзи, Конфуцій, Анаксимандр, Геродот, Геракліт, Емпедокл, Епікур, Цицерон, Платон, Аристотель, Аврелій Августин, Фома Аквінський, Н. Мак'явеллі, Е. Роттердамський, Т. Мор, Ф. Бекон, Т. Гоббс, Д. Лок, Д. Прістлі, Ш. Монтеск'є, Д. Дідро, Вольтер, Ж.-Ж. Руссо, А. Сміт, І. Кант, И.І. Фіхте, Г.В.Ф. Гегель, Ч. Дарвін, Л. Гумплович, Г. Спенсер, К. Маркс, М. Вебер та ін. [3; 5].

Конфрліктологічний аналіз історії розвитку фрілософрської думки дозволяє реконструювати й критично осмислити цілу низку конфліктологічних ідей, які репрезентовані у працях різних фрілософрів. Подібний аналіз був здійснений А. Анікіним, А. Анцуповим, А. Баллаєвим, М. Вебером, А. Гулигою, О. Еткіндом, Р. Коллінзом, I. Коном, Г. Майоровим, Р. Нуреєвим, В. Светловим, В. Семеновим, Ю. Смагіним, А. Шипіловим та ін. науковцями. Проте перераховані вчені не використовували у своїх дослідженнях інтегративний підхід, який дозволяе виявляти внутрішні зв'язки в системі конфрліктологічних знань, спадкоємність та взаємозумовленість тих чи інших ідей, які виникали у представників різних фрілософрських шкіл і напрямів.

Отже, інтегративне осмислення розвитку конфрліктологічних ідей в історії фрілософрської думки (зокрема, в період від Зигмунда Фройда до наших днів) не дістало належного розвитку в попередніх наукових дослідженнях вчених. Саме це і обумовило мету даної статті - проаналізувати найважливіші конфрліктологічні ідеї, які репрезентовані в історії фрілософрської думки (від Зигмунда Фройда до наших днів) крізь призму інтегративного підходу.

Перші дві статті, присвячені становленню і розвитку конфрліктологічних ідей в історії фрілософрської думки, були опубліковані нами в журналі Молодий вчений у 2021 р. Концептуальним методологічним ядром наших досліджень у цих статтях був інтегративний аналіз конфрліктів як складноорганізованих явищ [3; 5]. Тому і в даній статті інтегративний підхід базується на взаємодії історії фрілософрії, історії ідей та українознавства.

Виклад основного матеріалу. Психоаналітичний підхід у конфрліктології пов'язаний насамперед 3 іменем австрійського психолога Зигмунда Фройда, який створив одну 3 перших кониепиій людської конбліктності. Незважаючи на те, що Фройд займався переважно проблемами внутрішньо-особистісних конфрліктів, його заслугою є вказівка на необхідність пошуку причин міжособистісних конфліктів у сфрері несвідомого. Саме він створив учення про несвідолу сфберу особистості як основу багатьох конфрліктів [23].
Послідовник Фройда, австрійський психолог, психіатр і мислитель, творець системи індивідуальної психології Альфред Адлер (який ніколи не був прихильником фррейдистської тези про універсальну роль дитячої сексуальності у розвитку людської психіки) вбачав причину конфліктів індивіда з власним мікросередовищем у спробах індивіда звільнитися від почуття неповноцінності та домінування одних над іншими. На відміну від Фройда (який акцентував роль несвідомого та сексуальності як детермінант людської поведінки), Адлер наголошуе на важливій ролі соціального чинника, адже характер людини фрормуеться під впливом її «життевого стилю», тобто утвореної у дитинстві системи цілеспрямованих прагнень, в якій реалізуеться потреба у досягненні власної переваги, у самоствердженні як компенсації «колплексу леншовартос$\boldsymbol{m i » ~ ( А д л е р ~ у в і в ~ д а н и и ̆ ~ т е р м і н ~ у ~ н а у к о в и и ̆ ~ о б і г ) . ~}$ Розвиток особистості, за Адлером, залежить від того, яким чином цей комплекс буде компенсуватися. У патологічних випадках людина може намагатися компенсувати свій комплекс неповноцінності за рахунок прагнення до влади над іншими [7].

Американський dрілософр, психолог i соціолог Джордж Герберт Мід, будучи одним із представників символічного інтеракціонізму, належав до Чиказької соціологічної школи. У тогочасному науковому середовищі панував соціал-дарвінізм і теорія еволюції, які суттево впливали на розвиток соціології. 3 ідей Герберта Спенсера та Вільяма Самнера виник рух прагматизму, батьківщиною якого вважають США. Відповідно до прагматизму, сутністю людини є їі діяльність. Мід називав свою теорію «соиіальнили біхевіоризлиол", підкреслюючи як їі схожість, так і відмінність з біхевіоризмом Джона Бродеса Уотсона, цей напрямок панував у той час у психологічній науці. Мід розглядав людину як біологічну істоту, однак, на відміну від Уотсона, Мід надавав великого значення духовній активності, захищаючи свободу дій людини. У Міда (на відміну від біхевіористів) індивід є активним розумним суб'єктом. Увівши поняття «соціальний біхевіоризм», він прагнув відмежувати свою теорію від психоаналізу Фройда. Мід не вважав, що поведінка людини детермінована несвідомими психічними процесами, а свідомість він пов'язував із поведінкою суб'єктів, яку можна спостерігати у рамках соціальних процесів. Це стосувалось і конфрліктних ситуащій. Здатність особи розглядати ситуацію з точки зору іншої людини мислитель називае «прийняттял ролі іншого", це положення стало дуже важливим для наступних конфліктологічних досліджень. Припущення щодо можливості увійти в роль іншої людини у процесі соціальної взаємодії було зроблено ще Максом Вебером. Це припущення також розвивалось Ервінгом Гоформаном, який створив теорію стратегічного інтеракціонізму. Але Мід за допомогою концепиї прийнятmя ролі іншого намагався показати, що учасники соціальної взаємодії взаємно обмежують себе, коректують свої наміри у залежності від інтерпретації дій або реакцій іншої особи. Мислительні процеси у вигляді діалогу з самим собою форму- 
ють самосвідомість особи. Вчений справедливо підкреслює, що сприйняття Себе через Іншого $€$ необхідною передумовою виникнення людського «Я» (Self). За Мідом, соціальне йде попереду індивідуального, діючий суб'єкт має свободу волі, редрлексивне мінливе «Я» є джерелом соціальних змін [15]. Але, на жаль, основним недоліком теорії Міда є відсутність у ній історичного аспекта.

Американські психологи Карен Хорні, Epix Фромм, Луїс Генрі Салліван розширили розуміння природи конфрлікту, спробували внести у конфліктологічну проблематику соціальний контекст. Зокрема, Хорні основною причиною конфрліктів між індивідом та його оточенням вважала недолік доброзичливості з боку близьких людей, в першу чергу батьків. На думку Фромма, кондрлікти виникають через неложливість реалізувати в суспільстві особистісні прагнення і потреби. У 1920-1930-тих роках починають розвиватися соціально-психологічні аспекти конфоліктологічної проблематики [8; 17]. Зокрема, англо-американський психолог Вiльям Мак-Дугалл був переконаний, що конфрлікти в суспільстві неминучі, оскільки людям притаманні соціальні інстинкти типу страxy, стадності, салоствердження і т.п., які передаються спадково, саме тому люди постійно сперечаються, конфрліктують, вступають у протиборство. Підтримуючи тезу Дарвіна про те, що інстинкт боротьби за виживання забезпечуе існування та розвиток виду, Мак-Дугалл поширив це твердження й на людське суспільство. Створена ним теорія сочіальних інстинкmis мала багатьох прихильників, які сформували соціотропний напрямок у вивченні конфліктів [8; 17] (Сципіон Сігеле та ін.).

Американський психолог Курт Левін вивчав проблеми групової динаміки i розробив концепцію динамічної системи поведінки, яка перебуває у напруженому стані, коли поруиуеться рівновага між індивідом та середовищем. Ця напруга досить часто проявляеться у вигляді конфрліктної поведінки. Науковець підкреслив, що джерелом конфрліктів також може бути несприятливий стиль управління лідера групи. Левін був переконаний у тому, що оптилальнили шляхали вирішення конбліктів є реорганізація мотиваційних полів особистості й структури взаємодії індивідів [13].

Російський та американський соціолог і культуролог Питирим Сорокін є одним 3 основоположників теорій соціальної стратифрікації та соціальної мобільності. У вересні 1922 р., у віщі 33-х років, вчений був висланий з Росії за кордон, а вже у 1930 р. Гарвардський університет запросив Сорокіна стати деканом щойно створеного соціологічного фракультету. У 1965 р. видатний вчений стає Президентом Американської соціологічної асоціації. Сорокін зробив важливий внесок у розвиток сучасної конфліктології.

Досліджуючи соціальну роль покарань і нагород, яку вони виконують у системі соціальної взаємодії, Сорокін зазначав, що варто тільки вступити у процес спілкування двом або більшій кількості осіб (кожна з яких по-своєму розуміє специфріку належноӥ, реколиендованої та забороненої поведінки), то конфрлікт між ними буде неминучим. Правила поведінки суб'єктів соці- альної взаємодії Сорокін поділяв на дозволені, заборонені й реколендовані. Більш сильна частина суспільства, на думку вченого, нав'язує іншим свої шаблони поведінки, за допомогою різних стимулів - позитивних (нагороди) і $\boldsymbol{\mu}$ гативних (покарання). Нагороди й покарання, на думку вченого, є регуляторами внутрішньогрупової боротьби та кондрліктів. На основі аналізу історичного досвіду різних народів, вчений довів, що разом із ускладненням суспільного розвитку, із зростанням соціальної дифреренціації та розширенням соціальної взаємодії збільшується ивидкість зліни иаблонів поведінки. Вони стають більш гнучкими, легше піддаються змінам і через це вже не вимагають застосування жорстких стимулів (у вигляді жорсткого покарання й великої нагороди), які були характерними для ранніх історичних епох. Таким чином, по мірі культурного розвитку суспільства значення покарання й нагороди як регуляторів поведінки та чинників зменшення соціальних конфрліктів знижується. Визнаючи конфліктний характер історичного розвитку людського суспільства, Сорокін не вважає кондрлікти нормою життя, він засуджує їх і наголошує, що саме консенсус є правилом соціального життя і нормальним станом соціальної групи. Вчений виокремлюе сигнальну бункиію соціального конфлікту в соціальній групі і стверджує, що конфрлікт є показником «хворобливого» процесу всередині неї. Отже, наявність кондрліктів є симптомом і діагностичною ознакою неоднакового розуміння членами групи норм поведінки [21].

За Сорокіним, саме у боротьбі й зіткненні протиборчих сторін полягає зміст соціальних конфрліктів, саме «конфрліктний хід соціального розвитку» [22] зумовив появу соціальної системи і соціальну роль нагород і покарань. Адже безконфліктне й мирне взаємне ставлення членів групи один до одного за наявності конфрліктного стану їхніх норм належної поведінки можливе, у першу чергу, завдяки спільній дії мотиваційного та особистісно-фрормуючого впливу покарань і нагород. Сорокін виявив деякі законолірності конббліктної взаєлодї̈ сторін, які були обумовлені шаблонами поведінки взаємодіючих суб'єктів: 1) чим твердішими, стійкішими $€$ шаблони поведінки кожної 3 конфрліктуючих сторін, тим запеклішою й лютішою буде війна між ними, яка закінчується переважно знищенням однієї з ворогуючих сторін; 2) перемагаюча сторона у насильницький спосіб примушує переможених вчинити так, як вимагають шаблони

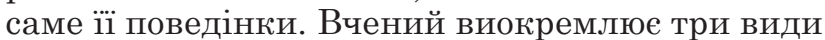
конфрліктів «шаблонів поведінки»: а) конфрлікти між індивідами; б) міжгрупові конфрлікти; в) конфлікт між особистістю та групою. Він вважав, що якщо «сторони зіткнулися», то результат зіткнення може бути таким: 1) подальше розз'єднання протиборчих центрів; 2) знищення одного (або обох центрів); 3) насильницькі дії переможця щодо переможеного центру. Вчений обгрунтував тезу про нелинучість $і$ всюдисуuустьь соціальних конфрліктів, стверджуючи, що жоден з існуючих «рецептів» щодо уникнення військових конфрліктів і громадянських воєн або інших форм кривавих міжусобиць, не може не тільки ліквідувати, але навіть помітно змен- 
шити ці конорлікти. Такими популярними «рецептами» $е$ передусім намагання ліквідувати війни й конфрлікти суто політичними засобами, зокрема, використовуючи демократичні політичні перетворення (сучасні дослідники вважають, що важливим чинником демократичних і політичних перетворень, а також консолідації суспільства є національна ідея [2]). Сорокін зазначав, що навіть якщо завтра весь світ стане демократичним, все одно війни та криваві сутички не зникнуть, оскільки демократії виявляються не менш войовничими і незлагідними із своїми сусідами, ніж автократичні режими [19]. Вчений одним 3 перших розглянув вплив голоду на поведінку людей та їхне суспільне життя. Ця праця $є$ надзвичайно актуальною для постколоніальної України [20].

Отже, погляди Сорокіна на різнопланові конфрлікти у суспільстві та між державами (маємо на увазі ті його праці, що стосуються розуміння причин конфрліктів, їхньої динаміки, внутрішніх закономірностей конфрліктної взаємодії) суттево вплинули на розвиток як соціології, так і конфрліктології. Важливою ідеєю відомого соціолога була також ідея інтегралізму, відповідно до якої соціологічне знання має розвиватися у бік створення узагальнюючої теорії структури й динаміки різних соціокультурних систем, а суперечливе різноманіття реально існуючих соціокультурних систем у перспективі буде трансформуватися у певний інтегральний соціокультурний лад. Соціологічна метатеорія повинна, на думку вченого, інтегрувати все соціогуманітарне знання свого часу в цілісну систему. Сорокін поставив завдання та окреслив перспективи об'єднання в ралках такої систели не тільки сочіогуланітарного, але й природничо-наукового знання [21].

Американський психолог, психіатр і соціолог Джекоб (Якоб) Леві Морено є засновником соціометрії, психодрами та групової психотерапії. За теорією соціометрії, яку він створив, ліжособистісні конбблкти визначаються станол елочійних відносин лію людьмu, їхніми симпатіями та антипатіями, які виникають у процесі формування позитивного, нейтрального чи негативного ставлення однієї особи до іншої. Морено був переконаний, що всі конфрлікти (від міжособистісних до міжнародних), можуть бути вирішені шляхом такої перестановки людей, яка буде відповідати їхнім емоційним вподобанням, щоб «соціометрична революція» уможливила гармонізацію суспільних відносин [16; 18].

Японський та американський соціолог, представник Чиказької школи Тамотсу Шибутані продовжив розвивати традиції символічного інтеракціонізму, його дослідження отримали широкий резонанс у контексті критики творів засновника символічного інтеракціонізму Міда. На думку Шибутані, причини конбліктів криються у салолу прочесі сочіальної взаєл㇒дї. При виникненні збурень у відносинах «індивід-середовище» суб'єкт починає відчувати внутрішню дисгармонію і дискомфорт. Прагнучи усунути їх, індивід здійснюе активні дії, щоб пристосуватися до середовища. В рамках таких процесів і виникають конфрлікти [24].
Початок етологічного nidxoдy в коноліктології було покладено у 1930-х роках дослідженнями австрійського зоолога й зоопсихолога, одного 3 основоположників етології, лауреата Нобелівської премії з фрізіології або медицини (1973) Конрада Лоренца. Вперше у світовій науці ним була висловлена гіпотеза про те, що головною причиною сочіальних конблікmiв є агресивність індивіда і натовпу. На думку Лоренца, механізми виникнення агресивності у тварин і людей однотипні, а агресія $є$ постійним станом живого організму [14]. Етологічні ідеї Лоренца розробляв також нідерландський етолог Ніколас Тінберген.

Отже, в історії розвитку конфрліктологічної думки у рамках зарубіжної фрілософрї̈, психології та соціології простежуються певні закономірності й концептуальне різноманіття. У другій половині XIX ст. дослідження конорліктів відбувалось у руслі соціал-дарвінізму та марксистської теорії. На рубежі XIX-XX ст. конфліктна проблематика опрацьовувалась у рамках соціально-політичних i правових концепцій суспільного розвитку людства. У цей час простежується значний інтерес дослідників до діалектичної концепції Гегеля, який розумів конфлікт як основу загального розвитку. У рамках тогочасної соціогуманітаристики поступово формувався конфліктологічний напрямок, котрий базувався, насамперед, на ідеях Карла Маркса, який підкреслював, що соціальний конфлікт $\epsilon$ найвищою формою прояву соціальних суперечностей, енергія яких може стати основним чинником суспільного прогресу.

На початку XX ст. починається поступова систематизація конфрліктологічних знань. У першій половині XX ст. найактивніше розроблялись функціональна теорія конфлікту Георга Зіммеля і структурний функціоналізм Талкотта Парсонса. Зокрема, німецький соціолог Зіммель описав конфрлікт як універсальне явище, яке виступає невід'ємною складовою соціальних відносин. Американський соціолог Парсонс, представник системно-фрункціональної школи, розглядав конфлікт як причину дестабілізації та дезорганізації суспільно-політичного життя. Він розумів конфлікт як аномалію суспільного життя, у зв'язку з чим головне завдання вбачав у підтримці безконфліктних відносин у суспільстві, що зможе забезпечити соціальну рівновагу, взаєморозуміння й співпрацю. При цьому інтегративну функцію мають виконувати правові інституції, релігія та звичаї, і саме тому 3 часом, на думку Парсонса, суспільство стане менш конфрліктним.

На становлення конфрліктології як науки суттево вплинули зарубіжні психологічні дослідження конфліктів першої половини XX ст. у рамках кількох напрямків: 1) психоаналітичного (З. Фройд, А. Адлер, К. Хорні, Е. Фромм); 2) сощіотропного (В. Мак-Дугалл, С. Сігеле та ін.); 3) етологічного (К. Лоренц, Н. Тінберген); 4) теорії групової динаміки (К. Левін, Д. Креч, Л. Ліндсей); 5) фррустраційно-агресивного (Д. Доллард, Л. Берковітц, Н. Міллер); 6) інтеракціоністського (Дж.Г. Мід, Т. Шибутані, Д. Шпігель); 7) поведінкового (А. Басс, А. Бандура, Р. Сірс); 8) сощіометричного (Д. Морено, Е. Дженігс, Г. Гурвич). 
$\mathrm{V}$ другій половині $\mathrm{XX}$ ст. поступово втрачають популярність так звані деструктивні концепції конфлікту як соціальної аномалії (Т. Парсонса, Е. Мейо). Основні конфрліктологічні дослідження відбувались у рамках теоріі позитивно-функціонального конфлікту Льюїса Козера, теорії конфліктної моделі суспільства Ральфа Дарендорфа та загальної теоpiї конфлікту Кеннета Боулдінга. Зокрема, німецький та американський соціолог Козер обгрунтував позитивну роль конфліктів у забезпеченні сталості соціальних систем. Теорія позитивно-функціонального конфлікту розглядае конфлікт як боротьбу за цінності, соціальний статус, владу, матеріальні та духовні блага. Це боротьба, в якій метою сторін є нейтралізація та знищення супротивника. Проте ця боротьба виконуе і позитивні функції: 1) надає можливість для виходу негативних емоцій; 2) під час конфрлікту люди краще пізнають один одного, а взаемне пізнання може трансформувати ворожі відносини у відносини співпраці. Соціальний конфлікт, на думку Козера, стимулюе соціальні зміни, появу нових суспільних порядків, норм та відносин [12; 29]. Англонімецький соціолог Дарендорф зазначае, що класовий конфлікт визначаеться, передусім, характером існуючої влади. Вчений вважае марними спроби ліквідації глибинних причин соціальних антагонізмів, але припускає можливість впливати на зміну специфіки перебігу конфлікту, що відкривае перед сучасним суспільством перспективу не революційних переворотів, а поступових еволюційних змін [11]. Загальна теорія конфлікту, запропонована американським соціологом Боулдінгом, яка репрезентована у його праці «Конфрлікт і захист» («Conflict and Defence: A General Theory», 1962), описуе дві моделі конфлікту - статичну й динамічну, що дає можливість зробити висновок: динаміка конфрікту е процесом, який відбуваеться внаслідок реакції протидіючих сторін на зовнішні стимули [9].

Спроба формування загальної теорії конфлікту у 1950-1970-тих роках базувалась на вивченні динамічно-структурних та фонкщіональних характеристик конфліктів. Особливо важливими у цьому контексті були ідеї: 1) К. Боулдінга та концепція інтегративної допомоги; 2) Дж. Бертона і теорія вродженої конфліктності та обов'язковості превентивних заходів; 3) Й. Галтунга та його роль у створенні теорії миротворчості; 4) Г. Кельмана, засновника теорії про акторів конфрлікту; 5) Г. Шміда, Т. Шеллінга, Р. Коллінза, К. Дойча та ін. [25; 26; 27; 28; 30; 31; 32].

На рубежі 1960-1970-х років починае формуватися самостійний напрям з вивчення переговорного процесу як частини конфліктної взаємодії. Найвідомішою е концепція Гарвардської школи конфліктології, що базуеться на інтерпретації конфлікту як конструктивної сили та концепції «принципових переговорів» Р. Фішера i У. Юрі. Концепція Гарвардської школи «Принципові переговори» обумовлюеться півстолітньою успішною традицією застосування даного методу для управління конфліктом, надання йому конструктивного характеру і досягнення оптимальних результатів у діалозі сторін. Дана концепція виходить з того, що сторони функціонують як вирішуючі загальну проблему ділові партнери, націлені на ефективне, розумне рішення при збереженні відносин, що орієнтуються, незалежно від ступеня взаємної довіри, на пошук спільних інтересів і взаемовигідних варіантів. Ця концепція зачіпає такі параметри комунікації: учасники, основа взаємодії (інтереси), рішення, критерії (аргументування) [30]. У наш час теорія і практика переговорного процесу розглядаються як один з перспективних напрямків конфріктології. Загалом ці дослідження зосереджені на вирішенні двох проблем: виявленні сукупності умов, що сприяють прийняттю конфліктуючими сторонами рішення приступити до переговорів, і вивченні процесу переговорів, коли конфліктуючі сторони вже прийняли рішення йти на пошук взаємних угод. Найрозробленішою є технологія переговорного процесу.

На межі XX-XXI ст. конфліктологічні дослідження спрямовані, передусім, на питання вивчення змін, яких може зазнавати конфлікт у процесі свого розвитку та за умов впливу на нього. Особливої актуальності у цей час набуло вивчення особливостей впливу на різнопланові конфлікти і засад контролю за ними, що чітко проявляеться у таких концепціях: теорія управління конфліктом, теорія врегулювання конфрлікту, теорія розв'язання конфлікту й теорія трансформації конфолікту. Нині конфрліктологічні дослідження у країнах Заходу здійснюються за такими напрямками: 1) теоретико-ігровий (який започаткував М. Дойч); 2) теорія організаційних систем (яку започаткували Р. Блейк, Дж. Мутон); 3) теорія і практика переговорного процесу (яку започаткували Д. Прюітт, Д. Рубін, Р. Фішер, У. Юрі).

Висновки і пропозиції. Отже, аналіз конфрліктологічних ідей в історії розвитку філософрської думки дозволив критично осмислити цілу низку роздумів, ідей та позицій зарубіжних вчених. Конфлікт ними розглядається і як руйнівна сила, і як спосіб вирішення накопичених суперечностей у процесах взаємодії різних суб'ектів (як індивідуальних, так і колективних).

Інтегративний підхід, який заснований на взаемодії історії фрілософрiї, історії ідей та українознавства, уможливив: 1) дослідження як окремих конфліктологічних ідей в істоpiї фрілософської думки, так і їхню взаємодію та взаємовплив; 2) виокремлення нових смислів із вже відомих концепцій; 3) відстеження як спадкоемності конфліктологічних ідей, так і специфіки збереження найкращих досягнень попередніх історичних етапів на наступних етапах розвитку філософрської думки; 4) аналіз наступності між різними конфліктологічними вченнями; 5) реактуалізацію тих конфліктологічних ідей, які не втратили своеї значущості до сьогодення і є важливими для припинення російсько-українського збройного конфлікту на теренах України, деконфліктизації українського суспільства та реінтеграції населення окупованих територій. Отже, конфліктологічні дослідження із залученням українознавства (з його трансдисциплінарним потенціалом) набувають все більшої ваги. 


\section{Список літератури:}

1. Авер'янова Н. Особливості збройного конфлікту в Україні. Украӥнознавчий альланах. 2019. Випуск 25. C. 8-13.

2. Авер'янова Н. Українська національна ідея в творчості В’ячеслава Липинського та їі роль у сучасному державотворенні. Вісник Київського національного університету ілені Тараса Шевченка. Серія «Українознавство». 2008. Випуск 12. С. 40-43.

3. Авер'янова Н.M., Воропаєва Т.С. Розвиток конфліктологічних ідей в історії фрілософрської думки (від Іммануїла Канта до Макса Вебера). Молодий вчений. 2021. № 7(95). С. 93-99.

4. Авер'янова Н.М., Воропаєва Т.С. Росія - Україна: міждержавний збройний конфрлікт неоколоніального типу. Молодий вчений. 2019. № 6(70). С. 264-267.

5. Авер'янова Н.М., Воропаева Т.С. Становлення і розвиток конфліктологічних ідей в історії фрілософрської думки. Молодий вчений. 2021. № 6(94). С. 128-136.

6. Авер'янова Н.М., Воропаєва Т.С. Стратегія «розумної сили» як основа для припинення збройного конфлікту в Україні та реінтеграції окупованих територій. Гілея: науковий вісник. 2019. Випуск 147 (№ 8). Ч. 2 . С. 7-13.

7. Адлер А. Наука жить. Київ : Port-Royal, 1997. 288 с.

8. Анцупов А.Я., Шипилов А.И. Проблела конфликта: аналитический обзор, междисииплинарный библиографбический указатель. Москва : ГАВС, 1992. 230 с.

9. Боулдинг Кеннет Э. Экономическая наука и социальные системы. Панорала эконолической мысли конца ХХ столетия. В 2-х толах. СПб. : Экономическая школа, 2002. Т. 2. С. 907-927.

10. Воропаева Т.С. Конфліктизаційні та деконфліктизаційні процеси в Україні: соціально-філософські аспекти. Научный взгляд в будуще. 2018. Вып. 10. Т. 2. С. 49-56.

11. Дарендорф Р. Совреленный социальный конфликт. Очерк политической свободы. Москва : «Российская политическая энциклопедия», 2002. 288 с.

12. Козер Л.А. Функиии социального конфблкта. Москва : Дом интеллектуальной книги: Идея-пресс, 2000.295 с.

13. Левин К. Разрешение социальных конфликтов. СПб. : Издательство «Речь», 2000. 408 с.

14. Лоренц К. Агрессия. Москва : Прогресс, 1994. 272 с.

15. Мид Дж. Г. Избранное : Сб. переводов. Москва, 2009. 290 с.

16. Морено Я.Л. Социолетрия: Экспериментальный метод и наука об обществе. Москва : «Академический проект», 2001.

17. Психология конфликта / Сост. и общ. редакция Н. Гришиной. СПб. : Питер, 2001. 448 с.

18. Сакс Дж.М. Голос Я.Л. Морено: Интервью с создателем психодрамы. Психодрала и современная психотерапия. 2003. № 1. C. 5-21.

19. Сорокин П. Человек. Цивилизация. Общество. Москва : Политиздат, 1992. 542, [1] с.

20. Сорокин П.А. Голод как фбактор. Влияние голода на поведение людей, социальную организацию и общественную жизнь. Москва : Academia \& LVS, 2003. XII, 678, [5] с.

21. Сорокин П.А. Систела социологии. Москва : Астрель, 2008. 1003 с.

22. Сорокин П.А. Социология революции. Москва : РОССПЭН, 2004. 659 с.

23. Фрейд 3. Введение в психоанализ : лекиии. Москва : АСТ, 2008. 608 с.

24. Шибутани Т. Социальная психология. Москва : Прогресс, 1968. 535 с.

25. Boulding K. Conflict and Defence. New York, 1968. XIV. 330 p.

26. Burton J. Sandole D. General Theory: The Basis of Conflict Resolution. Negotiations Journal. 1986. Pp. $333-344$.

27. Burton J. Dukes F. Conflict: Practices in Management. Settlement and Resolution. New York : St. Martins Press. 1990. XXIV. Pp. 145-146.

28. Collins Randall. Conflict Sociology: A Sociological Classic Updated. Abridged and updated by Stephen K. Sanderson. Boulder CO : Paradigm Publishers, 2009.

29. Conflict and Consensus: A Festschrift in Honor of Lewis A. Coser. Walter W. Powell and Richard Robbins (Editor). 1st edition. April 1, 1984. $436 \mathrm{p}$.

30. Fisher R., Ury W., Patton B. Getting to Yes: Negotiating Agreement Without Giving. New York : Penguin Books, 2011. 440 p.

31. Galtung J. Violence, peace and peace research. Journal of Peace Research. 1969. Vol. 6. No 3. Pp. $174-182$.

32. Krisberg L. Sociology of Social Conflict. New. York, 1973. XIV. Pp. 273-276.

\section{References:}

1. Averianova N. (2019) Osoblyvosti zbrojnogo konfliktu v Ukrayini [Features of the armed conflict in Ukraine]. Ukrayinoznavchyj almanax, issue 25, pp. 8-13.

2. Averianova N. (2008) Ukrayinska nacionalna ideya v tvorchosti Vyacheslava Lypynskogo ta yiyi rol u suchasnomu derzhavotvorenni [Ukrainian national idea in the works of Vyacheslav Lypynsky and its role in modern statehood]. Visnyk Kyyivskogo nacionalnogo universytetu imeni Tarasa Shevchenka. Seriya "Ukrayinoznavstvo", issue 12, pp. 40-43.

3. Averianova N.M., Voropayeva T.S. (2021) Rozvytok konfliktologichnyx idej v istoriyi filosofskoyi dumky (vid Immanuyila Kanta do Maksa Vebera) [Development of conflictological ideas in the history of philosophical thought (From Immanuel Kant to Max Weber)]. Molodyj vchenyj, no. 7(95), pp. 93-99.

4. Averianova N.M., Voropayeva T.S. (2019) Rosiya - Ukrayina: mizhderzhavnyj zbrojnyj konflikt neokolonialnogo typu [Russia - Ukraine: interstate armed conflict of the neocolonial type]. Molodyj vchenyj, no. 6(70), pp. 264-267.

5. Averianova N.M., Voropayeva T.S. (2021) Stanovlennya i rozvytok konfliktologichnyx idej v istoriyi filosofskoyi dumky [Formation and development of conflictological ideas in the history of philosophical thought]. Molodyj vchenyj, no. 6(94), pp. 128-136.

6. Averianova N.M., Voropayeva T.S. (2019) Strategiya «rozumnoyi syly» yak osnova dlya prypynennya zbrojnogo konfliktu v Ukrayini ta reintegraciyi okupovanyx terytorij [Strategy of «Smart power» as the basis for overcoming the armed conflict in Ukraine and the reintegration of occupied territories]. Gileya: naukovyj visnyk, issue 147 (no. 8), part 2, pp. 7-13.

7. Adler Alfred (1997) Nauka zhit [The science of living]. Kyiv: Port-Royal, 288 p.

8. Antsupov A.Ya., Shipilov A.I. (1992) Problema konflikta: analiticheskij obzor, mezhdisciplinarnyj bibliograficheskij ukazatel [Conflict problem: analytical review, interdisciplinary bibliographic index]. Moscow: GAVS, 230 p. 
9. Boulding Kenneth Ewart (2002) Ekonomicheskaya nauka i socialnye sistemy. Panorama ekonomicheskoj mysli koncza XX stoletiya. V 2-x tomax [Economic science and social systems. A panorama of economic thought at the end of the 20th century. In 2 volumes]. St. Petersburg: School of Economics, vol. 2, pp. 907-927.

10. Voropayeva T.S. (2018) Konfliktyzatsiyni ta dekonfliktyzatsiyni protsesy v Ukrayini: sotsialno-filosofski aspekty [Conflictization and deconflictization processes in Ukraine: social and philosophical aspects]. Nauchnyy vzglyad $v$ budushchee, issue 10, vol. 2, pp. 49-56.

11. Dahrendorf Ralf (2002) Sovremennyj socialnyj konflikt. Ocherk politicheskoj svobody [Contemporary social conflict. An outline of political freedom]. Moscow: «Russian political encyclopedia», $288 \mathrm{p}$.

12. Coser L. (2000) Funkcii socialnogo konflikta [Functions of social conflict]. Moscow: Dom intellektualnoj knigi: Ideya-press, $295 \mathrm{p}$.

13. Levin K. (2000) Razreshenie socialnyx konfliktov [Resolution of social conflicts]. St. Petersburg: Izdatelstvo «Rech», $408 \mathrm{p}$.

14. Lorenz K. (1994) Agressiya [Aggression]. Moscow: Progress, 272 p.

15. Mead J.G. (2009) Izbrannoe: Sb. perevodov [Selected: Collection of translations]. Moscow, 290 p.

16. Moreno J.L. (2001) Sociometriya: Eksperimentalnyj metod i nauka ob obshhestve [Sociometry: An Experimental Method and the Science of Society]. Moscow: «Academic project».

17. Psixologiya konflikta [Psychology of conflict] (2001). St. Petersburg: Piter, 448 p.

18. Sachs J.M. (2003) Golos Ya.L. Moreno: Intervyu s sozdatelem psixodramy [Voice of Ya.L. Moreno: Interview with the creator of psychodrama]. Psixodrama $i$ sovremennaya psixoterapiya, no. 1, pp. 5-21.

19. Sorokin P. (1992) Chelovek. Civilizaciya. Obshhestvo [Man. Civilization. Society]. Moscow: Politizdat, 542, [1] p.

20. Sorokin P.A. (2003) Golod kak faktor. Vliyanie goloda na povedenie lyudej, socialnuyu organizaciyu $i$ obshhestvennuyu zhizn [Hunger as a factor. The impact of hunger on human behavior, social organization and social life]. Moscow: Academia \& LVS, XII. 678, [5] p.

21. Sorokin P.A. (2008) Sistema sociologii [The system of sociology]. Moscow: Astrel,1003 p.

22. Sorokin P.A. (2004) Sociologiya revolyucii [Sociology of the Revolution]. Moscow: ROSSPEN, 659 p.

23. Freud Sigmund (2008) Vvedenie v psixoanaliz: lekcii [Introduction to psychoanalysis: lectures]. Moscow: AST, 608 p.

24. Shibutani T. (1968) Socialnaya psixologiya [Social psychology]. Moscow: Progress, 535 p.

25. Boulding K. (1968) Conflict and Defence. New York, XIV, $330 \mathrm{p}$.

26. Burton J., Sandole D. (1986) General Theory: The Basis of Conflict Resolution. Negotiations Journal, pp. $333-344$.

27. Burton J., Dukes F. (1990) Conflict: Practices in Management. Settlement and Resolution. New York: St. Martins Press, XXIV, pp. 145-146.

28. Collins Randall (2009) Conflict Sociology: A Sociological Classic Updated. Abridged and updated by Stephen K. Sanderson. Boulder CO: Paradigm Publishers.

29. Conflict and Consensus: A Festschrift in Honor of Lewis A. Coser (1984) / Walter W. Powell and Richard Robbins (Editor). 1st edition. $436 \mathrm{p}$.

30. Fisher R., Ury W., Patton B. (2011) Getting to Yes: Negotiating Agreement Without Giving. New York: Penguin Books, $440 \mathrm{p}$.

31. Galtung J. (1969) Violence, peace and peace research. Journal of Peace Research, vol. 6, no. 3, pp. $174-182$.

32. Krisberg L. (1973) Sociology of Social Conflict. New York, XIV, pp. 273-276. 